\title{
DID THE EUROPEAN UNIFICATION INDUCE ECONOMIC GROWTH? In SEARCH OF SCALE-EFFECTS AND PERSISTENT CHANGES
}

By

Patrick VANHOUDT

The University of Antwerp (UFSIA)

Prinsstraat 13, B-2000 Antwerp

Belgium

e-mail: patrick.vanhoudt@ufsia.ac.be
The Stockholm School of Economics, EIJS

Box 6501, SE-113 83 Stockholm

Sweden

e-mail: patrick.vanhoudt@hhs.se

\begin{abstract}
In this paper we investigate whether the European unification has had an impact on the Union's average labor productivity growth. Based on a time series approach we do not find a scale-effect as suggested by new growth theory. However, the data do not reject the bypothesis that the EU growth experience is well described by a textbook. Solow model. Panel data estimations moreover firmly reject the idea of a growth bonus associated with EU membership.
\end{abstract}

\section{JEL-classification code E13, F02, O52}

Key words

Integration, economic growth, time series tests, panel data evidence, EU membership

\section{WORKINg PAPER SERIES IN ECONOMICS AND FINANCE}

No. 270

OCTOBER 1998 


\title{
DID THE EUROPEAN UNIFICATION INDUCE ECONOMIC GROWTH? In SEARCH OF SCALE-EFFECTS AND PERsistent ChangeS
}

\author{
By \\ Patrick VANHOUDT \\ CONTENTS: I. Introduction; II. Time Series Properties of the Growth Rate in the European \\ Union; III. A Neoclassical Explanation; IV. Conclusion
}

\section{INTRODUCTION}

The European Union has steadily known an increase in the size of the market. According to 'new growth theory' this integration should have led towards higher long-run growth rates of per capita income. Neoclassical growth theory, however, disagrees with this conclusion: integrationlike any other change in economic policy-has at most a temporary effect on the growth rate. The issue is not without any policy relevance.

During the late fifties and until the mid eighties, the dominating paradigm in the field of economic growth was the simple yet elegant Solow-Swan exogenous growth model. In short, this model states that every period a fraction of income - generated by physical capital and labor-is forgone, and re-invested in physical capital. The latter is assumed to be subject to diminishing returns, so that investing a constant fraction of output will yield less additional output as time evolves. In the long run, the economy will therefore converge to a stable steady state in which the (per capita) income level is determined by the rate of capital accumulation, as well as by the exogenous growth rate of the number of efficiency workers plus some technological parameters. The long-run growth rate is solely determined by the growth rate of technology which is assumed to be exogenous, i.e. independent of economic behavior ${ }^{1}$. Changes in economic policy will

\footnotetext{
Remark: I would like to thank, without implications, George Akerlof, Magnus Blomström, Bruno de Borger, Lena Dahl, Walter Nonneman, Ari Kokko, Fredrik Sjöholm, Mathew Tharakan, Jürgen Vandenbroucke, an anonymous referee and the members of the electronic discussion list on economic growth (majordomo@ufsia.ac.be) for stimulating discussions or interesting comments. This paper was started while I was visiting the UC at Berkeley. Financial support from the Fund for Scientific Research, Flanders is greatfully appreciated.

${ }^{1}$ It is well known that this theory is unsatisfactory from a theoretical point of view. Neoclassical theory starts off from perfect competitive markets and a linearly homogenous production function with constant returns to scale. Under these conditions total output will be exactly exhausted by the distributive shares for all the input factorsphysical capital and labor-which is precisely Euler's theorem. Therefore it is not clear why technological changenotably the only possible engine of long-run growth in this story-would occur in the first place: it is a public good available and produced at no cost. Technology in this story is a "mystery variable" whose exact meaning is not specified and whose behavior is taken as exogenous. This means the theory leads to a dead end when it comes to understanding the details about technological change. Yet researchers have recently become interested again in the neoclassical approach. It appears that a Solow model augmented with elements from 'new' growth theory (see
} 
henceforth only have a temporary effect on the economy. So will integration. Due to possible differences in marginal productivity, opening borders in this theory may imply a re-allocation of capital and labor across the regions resulting in a temporary change of the growth rate. In the long run, however, the integrated economy will experience a constant per capita growth rate equal to the rate of technological change. Since technology is — and was-available at no cost as a perfect public good for all countries, there is therefore no reason to believe that the integrated economy as a whole-nor the economies taken separately-will experience a change of their long-run per capita growth rate compared to the long-run situation without integration.

Non-convex, neo-schumpeterian new growth theory-which arose in the literature around the mid eighties - takes another stand. Economies throughout history have been renovating and innovating from the inside. They did so presumably in response to forces endogenously determined by the market and institutions. Opening borders may change incentives in favor of faster technological change and hence economic growth.

The key in this theory is the observation that resulting new technology and knowledge is a special economic good (see Romer [1990]). New or qualitative superior goods appear in the economy because firms devote resources to research and development. They engage intentionally in R\&D because it may yield them a temporary monopoly power in the form of patent rights or royalties. Since the patent protection is limited in time new technology is only partially excludable-unlike a prefect private good. Contrary to a perfect public good, new technology is non-rival. Knowledge is written down in the patent so that it can be used as an input for further inventions at no additional cost, as often as desired, without limiting at all the use of the knowledge by others. Henceforth the innovator cannot capture all monopoly rents from his inventionprecisely the productivity gains of his piece of new knowledge in future innovations are not included. This incomplete appropriability of knowledge gives rise to what is commonly referred to as knowledge spill-overs ${ }^{2}$. Spill-overs imply that the neoclassical constant returns to scale assumption no longer holds on the aggregate level: doubling all production factors clearly leads to a more than proportional increase in output through the spill-overs associated with knowledge,

further) enables us to describe cross-country growth performances rather well (see e.g. Mankiw, Romer and Weil [1992] or Nonneman and Vanhoudt [1996]).

2 Not only R\&D generates knowledge spill-overs. Human capital accumulation is another factor which has been put forward to explain sustained growth (Uzawa[1964], Lucas [1988], Stokey [1988D. Like R\&D, human capital must have some effect that is internalized; otherwise no one would spend valuable resources to accumulate it. Yet people learn from one another so that the total gains of investments in human capital cannot be completely captured by the agent investing in it. 
hence: non-convex theory ${ }^{3}$.

In fact, the nucleus of this non-convex endogenous growth theory-the feature which makes sure that a model generates sustained endogenous long-run growth-is the so called scale effect: the larger the scale of an economy, the higher its long-run growth rate. The intuition behind this is twofold. First, an increase in the scale of an economy-in terms of e.g. population (market size), researchers or human capital units (which improve the efficiency of the research sector) increases the total impact of the spill-overs as well as the quantity of rents that can be captured by successful innovators. Second, the cost associated with a new invention is sunk and independent of the number of people who will use it. A larger population implies that this cost can be spread out over a larger base. Moreover 'wasteful duplication' can be avoided in an integrated economy through coordination policies. These factors should lead to a rise in innovative activity and hence spur economic growth ${ }^{4}$. In contrast to the neoclassical theory this has implications on the empirical side: new and increased growth rates should be permanent-there's no convergence to the old equilibrium — and growth rates should not be stationary around a steady state because of increases of the market size (see also Grossman and Helpman [1989], [1991], Rivera-Batiz and Romer [1991] and Aghion and Howitt [1992] for the relation between innovation, trade, scale and growth).

The example par excellence of successive increases in 'size of the economy'-both in terms of population and surface as well as in terms of GDP_clearly is the development of the European Union since the Benelux start in 1948. The interesting question from the point of view of growth theory is whether or not this continued integration has induced long-run growth effects. Our

\footnotetext{
${ }^{3}$ Convex new growth theory relaxes the assumption of decreasing returns to capital accumulation while markets are still perfectly competitive. The argument is that if capital and labor are easily substitutable-implying that the elasticity of substitution exceeds unity — production may eventually be possible without labor. Indeed, under these assumptions the accumulation of capital may drive out the non-reproducible factor (labor) so that long-run growth is no longer determined by exogenous factors. This type of new growth models is therefore known as 'AK-models (see e.g. Jones and Manuelli [1990] or Rebello [1991]). Such a scenario seems, however, highly implausible, and time series data reject these kinds of models based on their implications with regard to permanent effects (see e.g. Jones [1995]). Moreover, empirical results in estimating neoclassical production functions point in the direction of an elasticity of substitution smaller than one (e.g. Barro and Sala-i-Martin [1992] or Mankiw, Romer and Weil [1992] among many others).

${ }^{4}$ Only in the case of "equivalent innovation" there might be sustained growth without scale effects (see Young [1995]). Equivalent innovation refers to the fact that innovation improves the quality of an existing good only in the sense that it provides more utility (Young gives the example of the number and types of contraceptives). The higher quality has an impact on the level of utility, but it does not have, however, an impact on productivity growth. When utility improvements require higher efforts of research activity over time, a larger scale may only have demand-effects in that the profitability of an improvement increases. More research then does not necessary translate into higher real consumption possibilities or higher per capita incomes as no new goods or technologies appear on the market to improve the efficiency of production. It is, however, hard to believe that the post-war research activities were solely concerned with these kinds of innovations.
} 
objective is therefore to check whether the hypotheses that there exists a long-run time series relation between growth rates of per capita income and the scale of this EU-economy-and that its growth rate henceforth shows persistent changes — can be confirmed. This would strongly support the new growth ideas. The alternative testable hypothesis is given by the neoclassical theory which predicts that time series of growth rates after successive enlargements of the market will be rather flat, fluctuating randomly around a steady state growth rate, determined by economic fundamentals such as the behavior of the average investment share. We will also investigate whether or not there has been a "growth bonus" associated with EU membership.

\section{Time Series Properties of the Growth Rate in the European UNION}

In order to investigate the time series properties of the growth rate of the integrated economies, we have constructed weighted yearly data for the EU at its several stages as presented in table 1. Basic data come from the Penn World Tables (Mark 5.6). Table 2 shows the definition and source of the variables used in this paper; all data can be found in appendix I. Recall from the previous paragraph that stationary growth rates would support the neoclassical model, whereas a scale-effect in the growth rate series would support the 'new-growth' ideas. 
Table 1 - Chronology of the EU

\begin{tabular}{lll}
\hline \hline Name & Date Effective & $\begin{array}{l}\text { New Member } \\
\text { Countries }\end{array}$ \\
\hline \hline Benelux & January 1948 & $\begin{array}{l}\text { Belgium, } \\
\text { the Netherlands, } \\
\text { Luxembourg }\end{array}$ \\
& & $\begin{array}{l}\text { France, } \\
\text { West-Germany, }\end{array}$ \\
\hline \hline $\begin{array}{l}\text { "European Coal and Steal Community" } \\
\text { (ECSC), later extended (all sectors) as }\end{array}$ & July 1952 & Italy. \\
$\begin{array}{l}\text { Europe of the six, or "European Economic } \\
\text { Community" (EEC6) }\end{array}$ & January 1958 & \\
\hline \hline $\begin{array}{l}\text { Customs Union } \\
\text { Liberalization of movement of labor, } \\
\text { capital and services. }\end{array}$ & March 1968 & \\
\hline \hline Europe of the nine (EEC9) & July 1968 & Great Britain, \\
& January 1973 & Ireland, \\
& & Denmark \\
\hline \hline Europe of the ten (EEC10) & Greece \\
\hline \hline Europe of the twelve (EEC12) & January 1981 & Spain, \\
& January 1986 & Portugal \\
\hline \hline & & East-Germany - \\
& October 1990 & Gnification of \\
\hline \hline "European Union" (EU) & & Austria, \\
\hline \hline Europe of the fifteen (EU15) & January 1993 & Sweden \\
\hline \hline
\end{tabular}

Source: Web-site of the EU.

Table 2-Data description

\begin{tabular}{|c|c|c|}
\hline Variable & Definition & Source \\
\hline \multirow{6}{*}{$\begin{array}{l}\text { RGDPC=Y/L } \\
\text { RGDPW=y } \\
\text { POP } \\
\text { INV } \\
\text { EU-GDP } \\
\text { per capita }_{t}\end{array}$} & Real per capita GDP & Penn-World Table, \\
\hline & Real GDP per worker & mark 5.6 (NBER, \\
\hline & Population & Harvard) \\
\hline & Fraction of GDP invested in fixed capital & \\
\hline & $\sum^{\text {\#of members at time } t}\left(R G D P C_{E U \text { member }} \cdot P O P_{E U m e m b e r}\right)$ & \\
\hline & 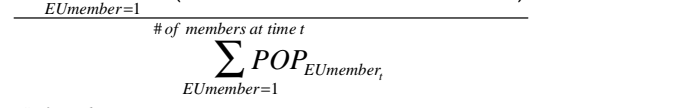 & \\
\hline \multirow[t]{2}{*}{$\begin{array}{l}\text { EU-GDP } \\
\text { per worker }_{t}\end{array}$} & $\sum_{\text {EUmember }=1}^{\# \text { of members at timet }}\left(R G D P W_{\text {EUmember }_{t}} \cdot P O P_{\text {EUmember }_{t}}\right)$ & \\
\hline & $\sum_{\text {EUmember }=1}^{\text {\#of members at time }}\left(\frac{R G D P C_{\text {EUmembe }_{t}}}{R G D P W_{\text {EUmember }_{t}}} \cdot P O P_{\text {EUmember }_{t}}\right)$ & \\
\hline \multirow{2}{*}{$\begin{array}{l}\text { EU-investment } \\
\text { share in physical } \\
\text { capital }_{t}\end{array}$} & $\sum_{\text {EUmember }=1}^{\# \text { of members at time } t}\left(I N V_{\text {EUmember }_{t}} \cdot R G D P C_{E_{\text {Unmember }}} \cdot P O P_{\text {EUmember }}\right)$ & \\
\hline & $E U R G D P C_{t} \cdot E U P O P_{t}$ & \\
\hline \multirow[t]{2}{*}{$\begin{array}{l}\text { Growth rate of a } \\
\text { variable }\end{array}$} & $\Delta\left(\right.$ variable $\left._{t}\right)$ & \\
\hline & variable $_{t-1}$ & \\
\hline
\end{tabular}

Following Jones [1995] we can now consider the following simple exercise, which should be seen 
as an illustration rather than as a test of a particular model. An economist living in 1970 in the European Economic Community of the six computes weighted data for the Benelux and the EEC6 based on the historical data from 1950-1970, just like we did. Thereafter he fits a constant and a time trend to the $\log$ of the per capita GDP for this time series on the European Community since 1950. Next he uses the regression results to forecast dynamically per capita GDP in 1990. For he could not possibly have foreseen whether or by how many countries the EEC would have expanded by 1990, advocates of new growth theory would argue that his prediction would significantly underestimate per capita GDP in the later and larger scale stages of the unification since the "scale-bonus" will not be reflected in his simple forecast.

Now, if we replicate this analysis, how far off would the prediction in fact be? We can use the prediction error from this constant growth path as a rough indicator of the importance of permanent movements in growth rates - if any—as suggested by new growth theory.

Figures 1 and 2 display the somewhat surprising result for this exercise in the light of the discussion of growth theory in the introduction. The prediction is off by as much as 28 percent of per capita GDP. Unfortunately the prediction overestimates per capita GDP rather than underestimating it, indicating that the average growth rate between 1970 and 1990 was actually significantly lower than during the interval 1950-1970.

Figure 1 - Average per Capita GDP in the European Union's different stages of development.

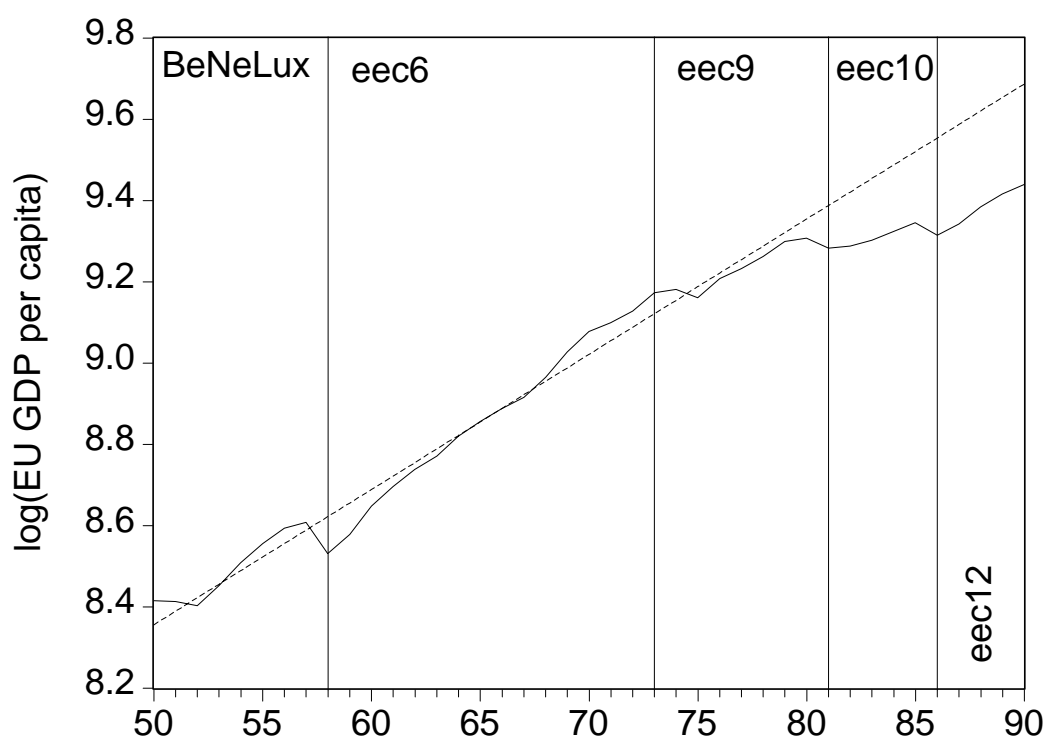

Note: the trend line represents the time trend calculated using data from 1950-70. 
This observation needs to be put somewhat in perspective, of course. In fact we should compare this result with the economic performance of a comparably large yet fully integrated economy. The same experiment was consequently done for the US economy. Surprisingly—or then maybe not since the scale of the US economy remained unchanged-the linear forecast overestimates US per capita GDP in 1990 only by an ignorable 5 percent (see figure 3). Therefore, our casual observation about the EU economy certainly deserves further investigation.

Figure 2 - Growth rates of per Capita GDP in the European Union's different stages of development.

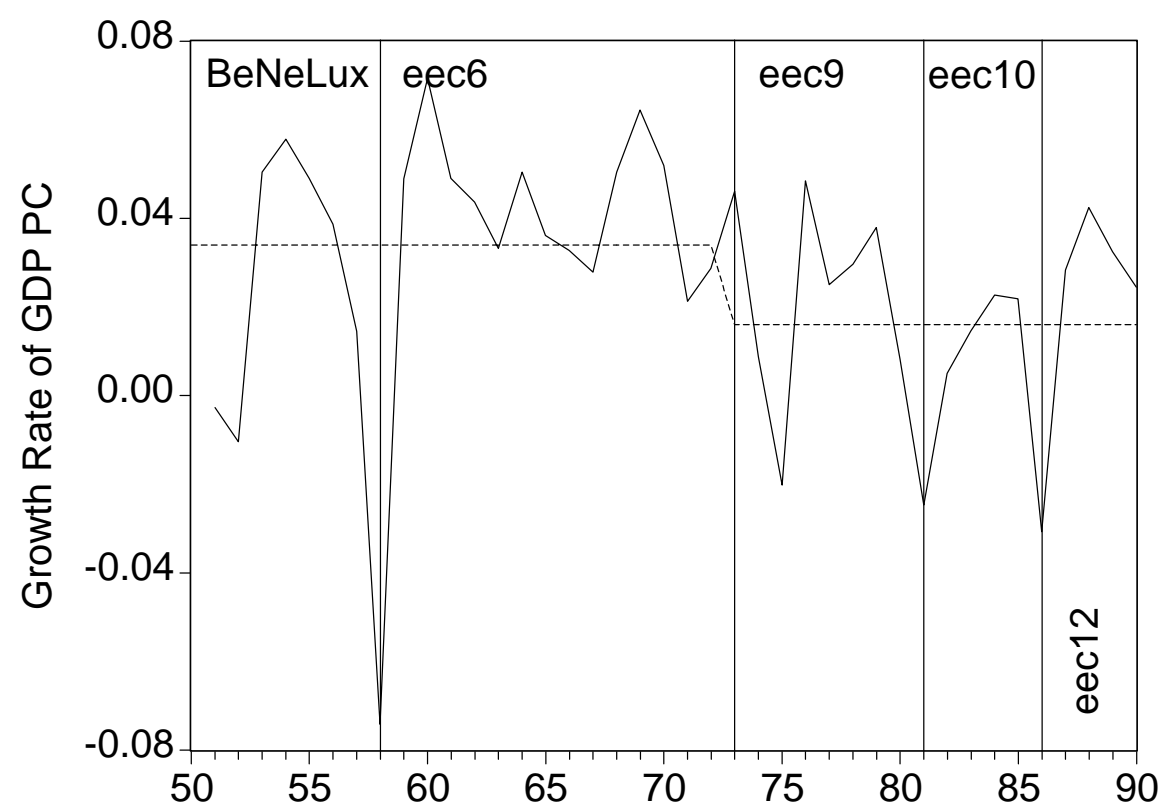

Note: the dotted line represents the fitted values for $\mathrm{g}_{\mathrm{t}}=\boldsymbol{\delta}+\boldsymbol{\gamma} . \mathrm{D}_{\mathrm{T}} *$ $\delta=3.4^{++}$percent, $\gamma=-1.8^{++}$percent (see table 3 ). 
Figure 3 - Actual vs. forecasted US per capita GDP

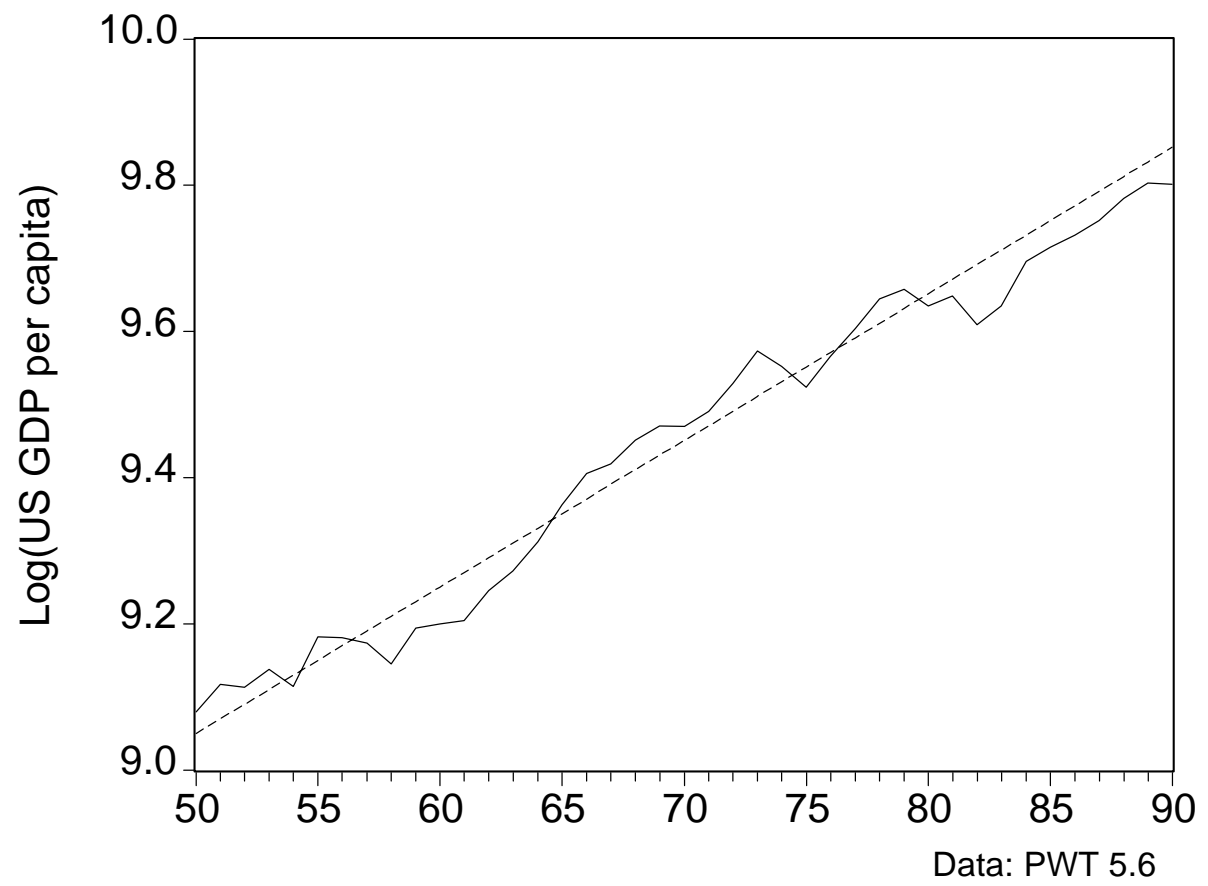

Note: the trend line represents the time trend calculated using data from 1950-70.

Table 3 consequently reports the results of some statistical tests on the EU growth rate time series. The methodology of the tests is described below the table.

Table 3 - Time series properties of post-war European growth rates, 1950-90.

\begin{tabular}{|c|c|c|c|c|}
\hline 1. Time Trend ${ }^{a}$ & $\begin{array}{l}\text { Coefficient } \\
b=-0.000381\end{array}$ & $\begin{array}{l}\text { SE } \\
0.000394\end{array}$ & $\begin{array}{c}\text { Test-stat } \\
-0.966504\end{array}$ & note \\
\hline 2. ADF Test ${ }^{b}$ & $\mu=-1.077545$ & 0.197474 & $-5.456652^{++}$ & $\begin{array}{l}\mathrm{k}^{*}=1, \\
\text { trend: } \\
\beta<0^{* *}\end{array}$ \\
\hline $\begin{array}{l}\text { 3. Endogenous Mean Shift }{ }^{c} \\
\text { 4. Difference in Means }{ }^{d}\end{array}$ & $\begin{array}{c}\gamma=-0.017793 \\
- \\
\Delta g=1.76 \%\end{array}$ & 0.008851 & $\begin{array}{c}-2.010199^{++} \\
2.17633^{++}\end{array}$ & $\mathrm{T}^{*}=1973$ \\
\hline $\begin{array}{l}\text { 5. F-Test Two-Sample for } \\
\text { Variances }^{\mathrm{e}}\end{array}$ & $\begin{array}{l}\sigma_{1}=9.38 \mathrm{E}-04 \\
\sigma_{2}=4.71 \mathrm{E}-04\end{array}$ & & $1.99372^{+}$ & $\begin{array}{l}\text { conclusion } \\
\text { in } 4 \text { does } \\
\text { not change } \\
\text { if } \sigma_{1}=\sigma_{2} \text { is } \\
\text { assumed }\end{array}$ \\
\hline $\begin{array}{l}\text { 6. ADF Test before Mean Shift }{ }^{\mathrm{b}} \\
\text { ADF Test after Mean Shift }\end{array}$ & $\begin{array}{l}\mu=-1.19975 \\
\mu=-1.278182\end{array}$ & $\begin{array}{l}0.273318 \\
0343621\end{array}$ & $\begin{array}{l}-4.389440^{++} \\
-3.719740^{++}\end{array}$ & $\begin{array}{l}\mathrm{k}^{*}=1 \\
\text { trend } \approx 0\end{array}$ \\
\hline
\end{tabular}

Note: ${ }^{+}$: significant at the 10 percent level, ${ }^{++}$: significant at the 5 percent level or better 


\section{Methodology:}

a.. The time trend reports the estimate of $\mathrm{b}$ from the regression $\mathrm{g}_{\mathrm{t}} \equiv \Delta \mathrm{y}_{\mathrm{t}} / \mathrm{y}_{\mathrm{t}-1}=\mathrm{a}+\mathrm{b} . \mathrm{t}$

b. The $\mathrm{ADF}$ equation reports the estimates of $\mu$ from the regression:

$\Delta \mathrm{g}_{\mathrm{t}}=\alpha+\beta . t+\mu \cdot \mathrm{g}_{\mathrm{t}-1}+\sum_{\mathrm{j}}^{\mathrm{k}} \delta_{\mathrm{j} \cdot} \cdot \Delta \mathrm{g}_{\mathrm{t}-\mathrm{j}}$. The test-statistic tests the null hypothesis of $\mu=0$. If the hypothesis of a unit root is rejected, the growth rate series is trend stationary which means that the growth rate randomly fluctuates around a trend.

Note: we use a fairly ad hoc method to determine the number of lags in the test equation. Following Perron [1989] we start with an a priori upper bound of $\mathrm{k}=8$. If this lag is not significant we reduce the number of lags until we obtain a significant one. If no lag is significant we set $\mathrm{k}=0$. The criterion for significance is a t-statistic of at least 1.6 in absolute value which corresponds to a significance level of almost 10 percent. The MacKinnon critical values for rejecting the hypothesis of a unit root were used.

c. In order to determine the mean shift the following equation is estimated: $g_{t}=\delta+\gamma$. $\mathrm{D}_{\mathrm{T}^{*}}$. The dummy $\mathrm{D}_{\mathrm{T}}$ takes the value of one for $t>T^{*}$. This equation is estimated for $T^{*} \in[1951-1989]$. We opted for $T^{*}$ which maximizes the absolute t-statistic for $\gamma$, thus we have chosen the break year which gives the highest probability of finding a level change in the growth rate.

d..'This reports the results of a t-tests to check whether the difference in means $(\Delta \bar{g})$ before and after the meanshift break found in c. is non-zero.

e. This reports the results of an F-test to check whether the variance before and after the mean shift found in c. is equal.

Although the time trend estimated over the whole sample is at first sight not significantly negative at the traditional confidence levels, an Augmented Dickey Fuller tests firmly rejects the hypothesis of a unit root indicating that the growth rates randomly fluctuate around a trend rate, which in this case is estimated significantly negative. We find a significant structural shift in the mean growth rate in 1973 which possibly drives the result concerning the trend. The average annual growth rate before the structural break was approximately 3.4 percent p.a. whereas this reduced to 1.6 percent p.a. afterwards. This difference in means is found to be statistically significant at the traditional confidence levels. Both before and after the break we tested for possible trends in the growth rates, which were not statistically different from zero. Apparently, the time series of EU per capita growth is thus stationary around two different trend lines which is confirmed by ADF tests for the different sub-periods-a unit root is in both cases rejected at the 5 percent level. The hypothesis of equal variances in the growth rates before and after the break is not rejected by an F-test at the same confidence level.

In short, time series statistics show that the level of EU output is well fit by a stationary growth process with a constant mean, which has shifted downward rather than upward as from 1973.

The finding of a stationary growth rate confirms the neoclassical prediction yet it does not suffice on itself to cast doubts on the validity of neo-schumpeterian new growth models. As described in the introduction, the steady state per capita growth rate in most of this new growth literature is a 
function of the scale of the economy. A cointegrating relation between growth rates and the scale of the economy would therefore still support the new growth ideas. However, the growth rates are integrated of order 0 , while the scale of the economy (e.g. measured by the GDP of the Union) may be integrated of a higher order. Therefore, we cannot always formally test for such a cointegrating relation. Regressions of the EU growth rate on total population, total workers or total GDP as measures of the scale of the economy, and a constant nonetheless yield a (negative) coefficient on the scale variable which is not statistically different from zero, a as can be seen from table 4. Growth rates of per capita EU income are thus apparently independent of the absolute scales.

Table 4 - results from regressions of the form $g_{t}=\rho+\chi$. scale, $1950-90$.

\begin{tabular}{llll}
\hline \hline Scale variable & \multicolumn{2}{c}{$\boldsymbol{\chi}$} & \multicolumn{1}{c}{ test-stat for $\chi$} \\
total population & $0.027^{++}$ & $-5.42 \mathrm{E}-09$ & -0.12 \\
total workers & $0.027^{++}$ & $-1.12 \mathrm{E}-08$ & -0.12 \\
total GDP & $0.032^{++}$ & $-3.20 \mathrm{E}-12$ & -0.94 \\
\hline \hline
\end{tabular}

Note: ${ }^{+}$: significant at the 10 percent level, ${ }^{++}$: significant at the 5 percent level or better

At this point the methodology may be criticized. As the data appendix clearly shows, there are discrete jumps in the constructed variables at the time of each enlargement which have not been accounted for. It therefore might be preferable to keep the sample of countries constant, for instance the EEC6, and examine how the growth rate for those countries has varied over time with each successive enlargement. Thus, instead of investigating the impact of the EU size on changing EU average per capita income, another appropriate way of testing for scale-effects would be to investigate the impact of the changing EU size on the economic performance of the original 6 members $^{6}$. Our conclusion, however, does not change if the sample is kept constant, which can intuitively be inferred from figure 47 : there is no growth-effect whatsoever resulting from the enlargement of the market.

\footnotetext{
${ }^{5}$ However, there may be a positive relation between the growth rate of output per worker and the scale of the manufacturing sector, see e.g. Backus et. al. [1992].

${ }^{6}$ We thank an anonymous referee for this suggestion.

${ }^{7}$ Formal econometric tests yield similar conclusions as those reached in table III.
} 
Figure 4 - Average economic performance of the EU6 countries, 1950-90.

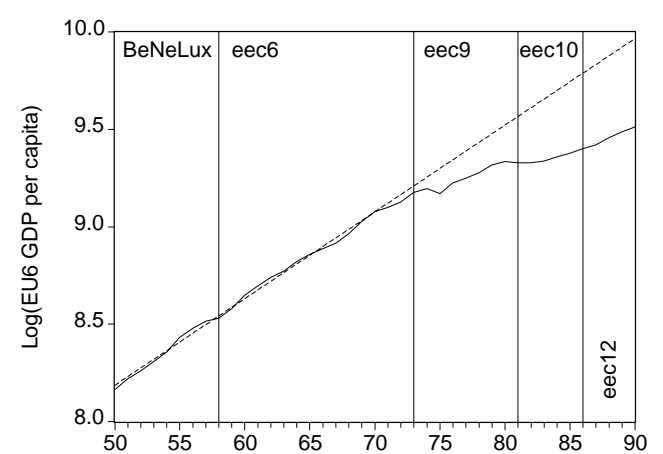

Data: PW'T 5.6

Note: the trend line represents the time trend calculated using data from 1950-1970.

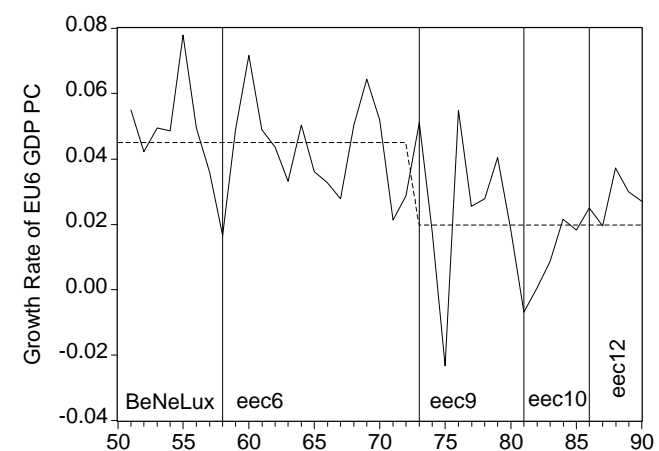

Data: PWT 5.6

Note: the dotted line represents the fitted values for $\mathrm{g}_{\mathrm{t}}=\delta+\gamma . \mathrm{D}_{\mathrm{T} *}$ with $\delta=4.5^{++}$percent and $\gamma=-2.5^{++}$percent.

Taken together, these findings are surely difficult to reconcile with predictions of non-convex endogenous growth theory. Both the stationarity and the independence of scale property of the EU growth rate as documented in the previous section are nevertheless compatible with neoclassical growth theory. In the next section we will argue that this paradigm is moreover useful to explain the downward shift in the long-run growth rate of the Union ${ }^{8}$. It will appear that there indeed is an important link between the evolution of the average investment share and the average growth rate.

\section{A NeOClassical EXPLANATION}

Figure 5, for instance, reveals the latter neoclassical hypothesis graphically. It plots the EU actual and average values for annual growth rates and investment shares in physical capital. As from 1973, the EU investment share has gone down significantly. In fact, it did more so than in other comparable countries. This can be concluded from table $\mathrm{V}$ which compares the changes in the EU-investment share with changes in the investment share for other OECD, non-EU countries. Average EU-investment relative to average EU-GDP apparently boosted more than proportional when the Union expanded for the first time, but the reductions later on were excessive compared to those of other developed countries. Table 6 reports the magnitude and the statistical

\footnotetext{
${ }^{8}$ Note that the 'supply shock' argument due to oil price changes does not suffice to explain the drop in the growth rate as from 1973 (which coincidentally falls together with the second enlargement of the EEC, but has been observed in other non-EC countries as well). The oil shocks in 1956-57 (Suez crisis), 1973 (Arab-Israeli war), 1979 (Iranian revolution) and 1990 (Iraq's invasion in Kuwait) are best viewed as one-time shocks-this has been documented in several studies, e.g. Raymond and Rich [1997]—which might have had a level effect yet no growth
} 
significance of the changes in the EU weighted investment share and growth rate in more detail. Lower average investment shares have led to slower enlargements of the average capital stock, and hence into a slowdown in growth of weighted average per capita GDP in the Union. This positive correlation between medium-run growth rates and average investment shares is one more feature supporting the neoclassical model (see e.g. Mankiw, Romer and Weil [1992]).

Figure 5 - Average and actual annual growth rates and investment shares (as a percentage of total EU GDP) in the European Union's different stages of development, 1950-90.

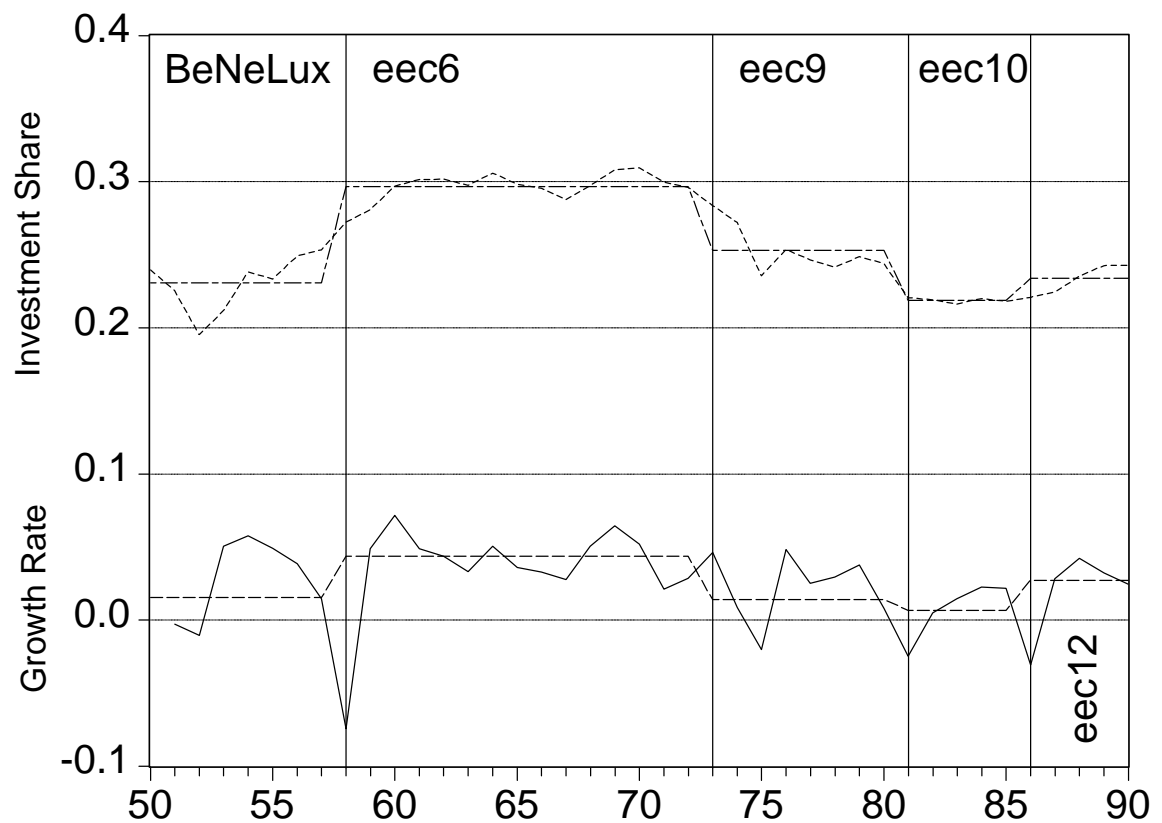

Table 5: Magnitude and changes in average annual EU weighted average investment shares, compared to average investment shares in non-EU OECD* countries at the times considered

\begin{tabular}{lcccc}
\hline \hline & $\begin{array}{c}\text { EU-investment } \\
\text { share as \% of EU } \\
\text { GDP }\end{array}$ & change & $\begin{array}{l}\text { Non-EU OECD- } \\
\text { investment share }\end{array}$ & change \\
\hline \hline BeNeLux & percent & percent & percent & percent \\
EEC6 & 23.07 & +28.52 & 27.40 & +16.20 \\
EEC9 & 29.65 & -14.64 & 26.92 & -19 \\
EEC10 & 25.31 & -13.59 & 24.18 & -10.18 \\
EEC12 & 21.87 & +6.63 & 25.44 & +5.21 \\
\hline \hline
\end{tabular}

*: OECD: Belgium, Netherlands, Luxembourg, France, Germany, Italy, UK, Ireland, Denmark, Greece, Spain, Portugal, Australia, Austria, Canada, Finland, Iceland, Japan, Norway, New-Zealand, Sweden, Switzerland, USA. 
Table 6 - Significance and magnitude of changes in annual EU weighted average growth rates and investment shares at the times considered.

\begin{tabular}{|c|c|c|c|c|}
\hline & $\begin{array}{c}\text { Change in } \\
\text { Growth Rates }\end{array}$ & t-test & $\begin{array}{c}\text { Change in } \\
\text { Investment } \\
\text { Share } \\
\end{array}$ & $\overline{\text { t-test }}$ \\
\hline & percentage points & & percentage points & \\
\hline BeNeLux-EEC6 & +2.84 & $1.76^{+} \mathrm{b}$ & +6.58 & $9.00^{++b}$ \\
\hline EEC6-EEC9 & -2.97 & $-3.57^{++\mathrm{a}}$ & - 4.34 & $-7.98^{++a}$ \\
\hline EEC9-EEC10 & -0.75 & $-0.53 \quad$ a & -3.43 & $-5.87^{++b}$ \\
\hline EEC10-EEC12 & +2.05 & $1.94^{++b}$ & +1.44 & $3.87^{++\mathrm{a}}$ \\
\hline
\end{tabular}

Note: $\quad$ a: F-test did not reject equal variances, ${ }^{b}$ : F-test rejected equal variances

${ }^{+}$: significant at the 10 percent level, ${ }^{++}$: significant at the 5 percent level or better

We can also formally derive direct testable equations from the neoclassical model, augmented with a possibility of an aggregate scale-effect, to check whether or not there is statistical support for its predictions in the Union. To see this, let:

$\mathrm{y}_{\mathrm{t}}=\mathrm{k}_{\mathrm{t}}^{\alpha} \mathrm{S}_{\mathrm{t}}^{\varphi}$

in which $\mathrm{y}$ and $\mathrm{k}$ denote output and capital per effective worker respectively, while $\mathrm{S}$ stands for a scale-index which is one at time zero, $\alpha$ is the share of physical capital in aggregate output and $\varphi$ is the elasticity of $y$ with respect to scale. By making use of the definition $d K / d t=s Y_{t}-\delta K_{t}$ and this production function it is straightforward to show that the steady state level of capital per worker is equal to the textbook Solow steady state augmented with the scale-index:

$\mathrm{k}_{*}=\left[\frac{\mathrm{s} \mathrm{S}^{\varphi}}{\mathrm{n}+\mathrm{x}+\delta}\right]^{\frac{1}{1-\alpha}}$

Provided that $\varphi$ is positive, a larger scale thus implies that the economy converges to a larger amount of physical capital per effective worker, and hence to a higher per capita income in the long-run. By substituting equation (2) in (1) and taking logarithms we indeed obtain that

$\log \left[\frac{\mathrm{Y}}{\mathrm{L}}\right]_{*}=\mathrm{const}+\frac{\alpha}{1-\alpha} \log [\mathrm{s}]-\frac{\alpha}{1-\alpha} \log [n+x+\delta]+\frac{\varphi}{1-\alpha} \log [\mathrm{S}]$

Obviously, integrating with an economy which leads to a reduction of the average investment share s will have a negative impact on per capita income of the integrated economy in the longrun unless it is compensated by a scale-effect. 
It is important to note that for a given scale this approach implies the "conditional convergence" property which characterizes neoclassical models ${ }^{9}$. The convergence equation has been derived by Barro and Sala-i-Martin [1992] as a log linear approximation of the adjustment process to the steady state, and can in our case be written as:

$$
\begin{aligned}
\log \left[\frac{\mathrm{Y}_{\mathrm{t}} / \mathrm{L}_{\mathrm{t}}}{\mathrm{Y}_{0} / \mathrm{L}_{0}}\right]_{\mathrm{i}} & =\left(1-e^{-\lambda t}\right)\left(\text { const }+\frac{\alpha}{1-\alpha} \log [\mathrm{s}]_{\mathrm{i}}-\frac{\alpha}{1-\alpha} \log [n+x+\delta]_{\mathrm{i}}\right. \\
& \left.+\frac{\varphi}{1-\alpha} \log \left[\mathrm{S}_{\mathrm{i}}\right]-\log \left[\frac{\mathrm{Y}_{0}}{\mathrm{~L}_{0}}\right]_{\mathrm{i}}\right)+u_{i}
\end{aligned}
$$

with $\mathrm{s}$ being the average investment share in physical capital, $\mathrm{n}$ the average growth rate of employment over the period $[0, \mathrm{t}]$, and $\lambda=(1-\alpha)(\mathrm{n}+\mathrm{x}+\boldsymbol{\delta})$.

Usually cross-country or cross-region data are employed to verify the convergence equation. An important hypothesis to test in (4) then is the significance and magnitude of $\lambda$, the speed of convergence. According to the neoclassical assumptions, the sum of the coefficients on the investment share (in $\operatorname{logs}$ ) should moreover be equal to the negative coefficient on $\log (n+x+\delta)$, and the capital share-which can be computed from the estimated coefficients—should be around one third to 0.4 according to the growth accounting literature. These are additional testable hypotheses.

Yet we can also view the convergence hypothesis in a time-series set-up as an adjustment process around a cointegration relationship, and the convergence equation in (4) as a non-fully specified error correction model. Equation (4) can be generalized to allow for adjustment costs as:

\footnotetext{
${ }^{9}$ In neoclassical models, the growth rate has a 'convergence' property as described in the introduction. Starting from a Cobb-Douglas constant return production function of the form $\mathrm{Y}=\mathrm{K}^{\alpha}(\mathrm{AL})^{1-\alpha}$ — with capital $(\mathrm{K})$, labor $(\mathrm{L})$ and technology (A) being the inputs-it can be shown that the rate of convergence towards the long-run equilibrium is given by $\lambda=(1-\alpha)(n+x+\delta)$ (see e.g. Barro and Sala-i-Martin [1995]). In this expression $\alpha$ stands for the capital share in GDP, $\mathrm{n}$ is the growth rate of the work force, and $\mathrm{x}$ and $\delta$ are technology parameters which indicate the exogenous rate of technological change and depreciation respectively. Using some plausible values for these parameters yields a theoretical expected value for this speed of convergence. If we for instance take 2.5 percent for $\mathrm{x}$ (this is the average of the steady state growth rates before and after the break), 5 percent for $\delta$ and 2 percent for $n$ (i.e. the average growth rate of the working force in the EU with exception of the one time change from the BeNeLux to EEC6), a capital share of typically one third will result in a speed of convergence of a little over 6 percent p.a.
} 


$$
\begin{aligned}
\log \left[\frac{\mathrm{Y}_{\mathrm{t}} / \mathrm{L}_{\mathrm{t}}}{\mathrm{Y}_{\mathrm{t}-1} / \mathrm{L}_{\mathrm{t}-1}}\right] & =\left(1-e^{-\lambda t}\right)\left(\mathrm{const}+\frac{\alpha}{1-\alpha} \log \left[\mathrm{S}_{\mathrm{t}}\right]-\frac{\alpha}{1-\alpha} \log \left(n_{t}+x+\delta\right)\right. \\
& \left.+\frac{\varphi}{1-\alpha} \log \left[\mathrm{S}_{\mathrm{t}}\right]-\log \left[\frac{\mathrm{Y}_{\mathrm{t}-1}}{\mathrm{~L}_{\mathrm{t}-1}}\right]\right)+\sum_{i} a_{i} \log \left[\frac{\mathrm{Y}_{\mathrm{t}-\mathrm{i}} / \mathrm{L}_{\mathrm{t}-\mathrm{i}}}{\mathrm{Y}_{\mathrm{t}-\mathrm{i}-1 / \mathrm{L}_{\mathrm{t}-\mathrm{i}-1}}}\right]+e_{\mathrm{t}}
\end{aligned}
$$

How well would this equation fit the EU growth process? Would the regression results confirm the textbook model's theoretical hypotheses as put forward earlier? If so, then the coefficient on the scale-index, $\varphi /(1-\alpha)$, will presumably be estimated close to zero, possibly not significant. This would be additional support for the absence of a scale-effect in the aggregate EU growth rate.

Table 7 reports interesting regression results in this respect. Remarkably, non of the built-in neoclassical hypotheses are rejected, whatever scale-index is used. Moreover, the coefficient on the scale-index is not significant at the traditional confidence levels in none of the regressions, which reinforces the cross-section results reported in Barro and Sala-i-Martin [1995]. In fact, Ftests did not reject the hypothesis that the scale-variable is a redundant variable in these regressions. Variations in the EU growth rate seem for over 90 percent well described by the two neoclassical growth fundamentals, investment in physical capital and the growth rate of the working population. 
Table 7 - A time series test of the neoclassical convergence equation. Dependent variable is the annual growth rate of income per worker $\left(g_{t}\right)$, 1950-90

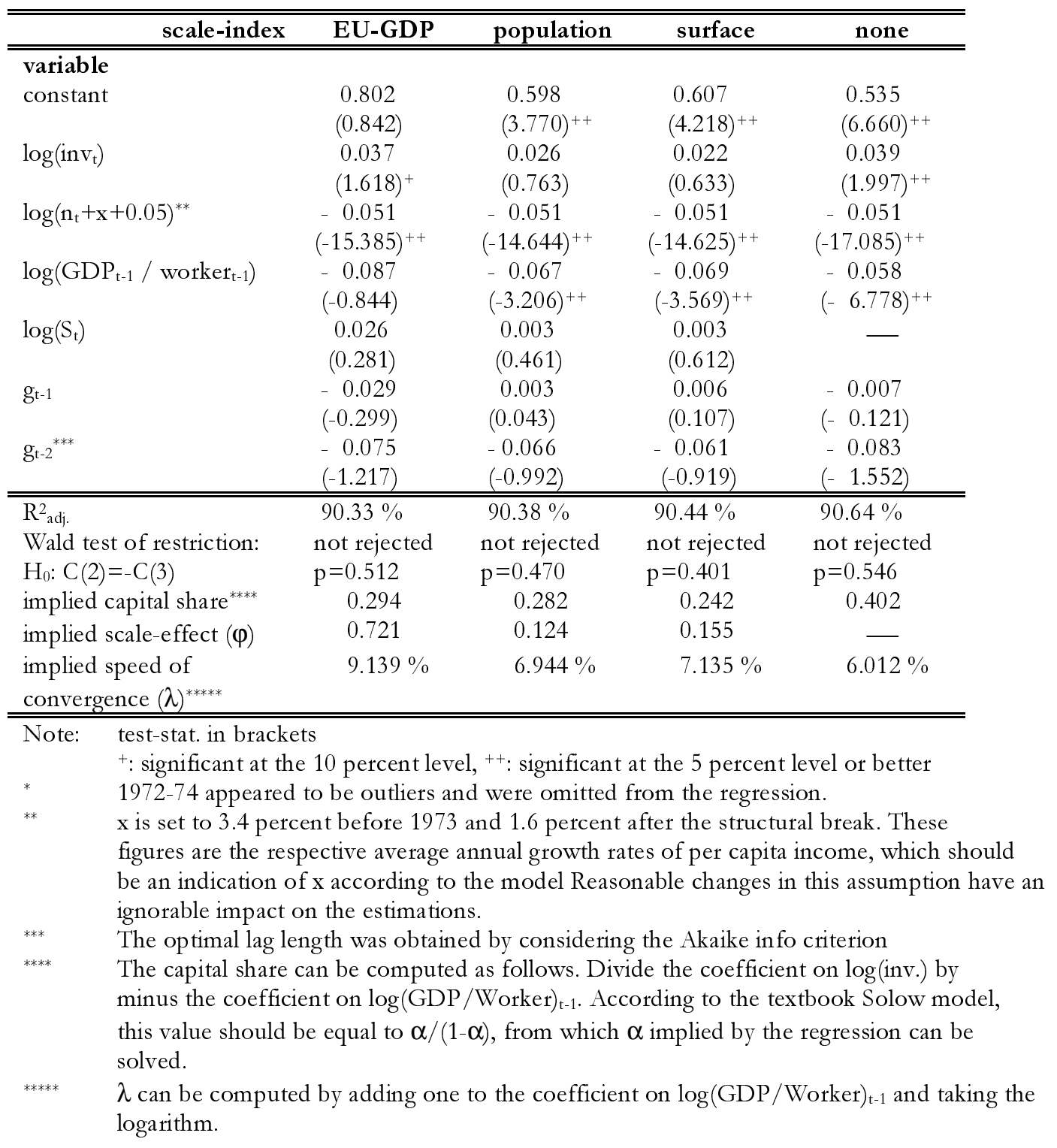

As we already noted earlier, the aggregated average EU-investment share has decreased sharper than it did in comparable non-EU OECD countries at the time (see table 5), which may explain the significant overestimation of the forecast of $\log (\mathrm{GDP})$ in the thought experiment we considered earlier. It is, however, beyond the scope of this paper to investigate why the aggregated EU-investment share has reduced, or why scale-effects which may exist at the manufacturing sector (see e.g. Backus et. al. [1992]) do not show up at the aggregate level. Often heard arguments are that the growing cost of the EU bureaucracy, or the installment of antigrowth social programs (Baldwin and Seghezza [1996]) lie at the very heart of this. But one could for instance evenly well argue that integration induces firmer competition on the output market so that a number of firms will prove unable to compete (e.g. because of higher labor costs 
and/or social security taxes) and begin to desinvest.

We thus have made clear two things so far, being: 1. the enlargement of the market size in Europe did apparently not result in a scale-effect in the growth rate of average EU labor productivity, and 2. the growth experience during the development of the EU is well described by a textbook neoclassical model which emphasizes the role of investment as engine of growth. However, we did not yet provide evidence yet that EU membership per se did or did not result in a long-run growth bonus. This is what we will do next.

In order to investigate the impact of EU membership on economic performance in the long-run we have put together a panel of data. The panel consists of 5 observations for every of the 23 OECD countries. Each of the 5 observations refers to one of the EU stages, i.e. observation 1 refers the BeNeLux period, observation 2 to the EC6 period, observation 3 to the EC9 period, observation 4 to the EC10 period and observation 5 to the EC12 period. The hypothesis we are interested in is whether or not EU membership in the considered time span had a positive impact on economic growth compared to developed countries which did not join the EU.

Our analysis is carried out stepwise, as reported in table 8, going from a basic intuitive to a more theoretically motivated test. The dependent variable is the growth rate of income per worker over the considered EU stage. Every regression-all OLS - contains an intercept so that 22 country dummies and 4 time dummies (which reflect the 4 latest EU stages) are left over to be taken up to deal with fixed effects.

In the basic regression (R1), the only substantive regressor is the dummy for EU-membership. It is not statistically significant at the conventional confidence levels, indicating that no growth bonus was obtained by being a member of the EU compared to being a non-EU OECD country. Regression (R2) allows for another regressor in this respect, namely the number of years that a country has been a member of the EU by the end of the particular stage. The length of EUmembership also appears not to be significant.

Judging the impact of EU solely based on a dummy is, however, questionable. Although we are considering highly developed countries and controlled for fixed effects a dummy may primarily capture country characteristics rather than effects of integration. Tests which only take into account a membership-dummy indeed ignore other factors influencing economic growth as set 
out previously, such as e.g. initial conditions, investment shares etc.

Therefore, we augment the neoclassical convergence equation-to be more precisely equation (4) -with the membership and membership length dummies (as well as with the fixed effect dummies) in regressions (R3) and (R4) respectively. The scale-variable considered here is the average population size in the (integrated) economy at the particular EU stage. Thus, during the BeNeLux stage the scale for Belgium, the Netherlands and Luxembourg is the same and equals the average population of the three countries over the time span 1950-1957, while other countries' scale-variable equals their own average population over that period, and so forth. The other independent variables are the log of the average investment share, the log of the average growth rate of employment plus 5 percent (which should be indicative for $x+\delta$ ), and the initial income at the beginning of the stage.

The results of this estimation indicate that there is no convincing evidence to support the idea of a long-run growth bonus associated with EU membership, nor with membership length, even if controlled for factors which have an impact on countries' steady state income level. Larger countries also do not seem to grow faster. Moreover, the neoclassical hypotheses are again not rejected by the data. 
Table 8 - Panel data estimations (1950-1990). Dependent variable is $\log \left[y_{t} / y_{0}\right]$, with $y_{0}$ and $y_{t}$ being per capita income at the beginning and end of each EU-stage.

\begin{tabular}{|c|c|c|c|c|}
\hline \multicolumn{5}{|l|}{ variable: } \\
\hline Constant & $\begin{array}{l}0.221 \\
(3.597)^{++}\end{array}$ & $\begin{array}{l}0.221 \\
(3.529)^{++}\end{array}$ & $\begin{array}{l}4.344 \\
(6.181)^{++}\end{array}$ & $\begin{array}{l}4.344 \\
(6.181)^{++}\end{array}$ \\
\hline EU-member $(0 / 1)$ & $\begin{array}{c}0.024 \\
(0.506)\end{array}$ & $\begin{array}{c}0.024 \\
(0.438)\end{array}$ & $\begin{array}{c}0.001 \\
(0.016)\end{array}$ & $\begin{array}{l}-0.014 \\
(-0.258)\end{array}$ \\
\hline $\begin{array}{l}\text { Length of } \\
\text { membership }\end{array}$ & - & $\begin{array}{l}8.64 \mathrm{E}-05 \\
(0.036)\end{array}$ & - & $\begin{array}{c}0.003 \\
(1.410)\end{array}$ \\
\hline $\log ($ inv. $)$ & - & - & $\begin{array}{l}0.235 \\
(2.782)^{++}\end{array}$ & $\begin{array}{l}0.289 \\
(3.132)^{++}\end{array}$ \\
\hline $\log (n+0.05)$ & - & - & $\begin{array}{l}-0.203 \\
(-1.951)^{++}\end{array}$ & $\begin{array}{l}-0.235 \\
(-2.218)^{++}\end{array}$ \\
\hline $\log ($ Scale $)$ & - & - & $\begin{array}{l}0.019 \\
(1.124)\end{array}$ & $\begin{array}{c}0.013 \\
(0.769)\end{array}$ \\
\hline $\log \left(y_{0}\right)$ & - & - & $\begin{array}{l}-0.460 \\
(-8.331)^{++}\end{array}$ & $\begin{array}{l}-0.470 \\
(-8.494)^{++}\end{array}$ \\
\hline Time dummies (4) & rejected & rejected & rejected & rejected \\
\hline Wald Test: $\mathrm{H}_{0}$ : all are 0 & $\mathrm{p}=0.000^{++}$ & $\mathrm{p}=0.000^{++}$ & $\mathrm{p}=0.000^{++}$ & $\mathrm{p}=0.000^{++}$ \\
\hline Country dummies (22) & rejected & rejected & rejected & rejected \\
\hline Wald Test: $\mathrm{H}_{0}$ : all are 0 & $\mathrm{p}=0.001^{++}$ & $\mathrm{p}=0.001^{++}$ & $\mathrm{p}=0.021^{++}$ & $\mathrm{p}=0.018^{++}$ \\
\hline \# obs & 115 & 115 & 115 & 115 \\
\hline $\mathrm{R}_{\text {adj }}^{2}$ & $76.30 \%$ & $76.03 \%$ & $87.14 \%$ & $87.30 \%$ \\
\hline SER & 0.125 & 0.126 & 0.092 & 0.091 \\
\hline $\begin{array}{l}\text { Wald test of restriction: } \\
\mathrm{H}_{0}: \mathrm{C}(4)=-\mathrm{C}(5) \\
\text { implied capital share }\end{array}$ & - & - & $\begin{array}{l}\text { not rejected } \\
\mathrm{p}=0.815 \\
0.338\end{array}$ & $\begin{array}{c}\text { not rejected } \\
\mathrm{p}=0.690 \\
0.381\end{array}$ \\
\hline implied scale-effect & - & - & 0.079 & 0.045 \\
\hline $\begin{array}{l}\text { implied speed of } \\
\text { convergence* }^{*}\end{array}$ & - & - & $6.157 \%$ & $6.355 \%$ \\
\hline $\begin{array}{ll}\text { Note: } & \text { test-stat. in brack } \\
& + \text { : significant at tl } \\
& * \text { : for an averag }\end{array}$ & $\begin{array}{l}0 \text { percent } \\
\text { iod lengtl }\end{array}$ & ignificat & 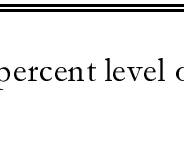 & \\
\hline
\end{tabular}

Our results relate in fact very well to the conclusions reached in the empirical studies so far on the issue of growth effects of European integration, although virtually all of them lack formal theoretical reasoning-both the specifications and the chosen control variables are intuitively appealing but also usually ad hoc. In the cross-country literature Landau [1995] for instance finds no growth benefits whatsoever for EU members compared to countries of a similar stage of development who did not join the EU. This reconciles with the conclusion of De Melo et. al. [1992] who used the ad hoc Barro [1991] technique in a cross-section of 101 countries and did not find growth effects associated with EU integration. Henrekson et. al. [1997] report that the EC/EFTA dummy is significant if one runs a cross-country growth regression on a sample of 22 countries. They find that this relation is, however, not robust with respect to the set of control variables and that there are no significant differences between the effect of EC or EFTA membership on economic growth. Baldwin [1996], in contrast, finds that cross-country data 
reveal a rough correlation between the national total factor productivity growth rates and the degree (and duration) of European Integration. However, his exploratory regressions into this phenomenon prove inconclusive, and he finds almost no econometric support for trade-induced technology-led growth associated with European integration. In an attempt to estimate dynamic effects of integration based on a time series analysis for six integration schemes (among which EC and EFTA), Brada and Méndez [1988] are unable to report that integration (except for the Latin Free Trade Area (LAFTA) and the Council for Mutual Economic Assistance (CMEA)) implies faster productivity effects, and conclude that the argument of dynamic effects cannot serve as rationale for integration.

\section{CONCLUSION}

The European Union has steadily known an increase in the size of the market. According to 'new growth theory' this integration should have induced higher long-run growth rates of per capita income — or equivalently: aggregated labor productivity — in the integrated economy. Neoclassical growth theory, however, disagrees with this conclusion: integration-like any other change in economic policy-has at most a temporary effect on the growth rate. The issue is not without any policy relevance.

Based on time series data for the EU at several stages, we investigated whether or not the increase in scale induced permanent changes in the growth rate of aggregate labor productivity. We did find a permanent shift, but it was a downward one, rather than an upward movement as suggested by new growth theory. The structural break is situated in 1973 when the EEC coincidentally enlarged for the second time. The time series for the growth rate are stationary around the two trend lines before and after the break.

We do not pretend to have tested the neo-schumpeterian endogenous growth theory. We have rather provided some statistical properties of the EU growth time series which at least are hard to reconcile with this non-convex 'new' growth theory. In stead the data do not seem to contradict a neoclassical framework in which scale effects are absent, and which devotes the slowdown simply to reductions in the average investment shares which have accompanied the EU enlargement.

We found three important indications which support the latter theory in explaining the EU growth experience. The stationarity property of the growth rates in fact can be interpreted as a 
first indication in favor of the neoclassical Solow theory. A second indication comes from the significant co-movement of investment shares and medium-run growth rates.

The neoclassical model — which we augmented with a scale-variable—also provides us with a direct testable equation, i.e. the convergence equation. This equation was estimated for the period 1950-90. None of the built-in neoclassical hypotheses (speed of convergence, capital share, and restrictions on the coefficients) were rejected, whatever scale index was employed. Variations in the EU growth rate between 1950 and 1990 are for over 90 percent due to, and well described by changes in only two fundamentals: investment in physical capital and the growth rate of the working population. This is a third confirmation of the theory.

The European unification may have led to an increase of trade flows. Products from every member country are indeed readily available all over the EU. In this sense the unification might have induced higher utility of its inhabitants. However, we are unable to report that the unification caused more rapid growth of per capita income (or equivalently: a slower productivity slowdown) compared to other non-EU OECD countries. In other words, although integration possibly had trade effects there were no growth effects associated with EU membership. This reconciles with earlier reported cross-country findings.

As far as policy conclusions can be drawn from this exercise, the findings indicate that-in addition to the emphasis on nominal convergence measures such as e.g. the (highly ad hoc) monetary criteria for member countries to join the monetary union-a criterion on the real side of the economy needs to be applied as well. If increasing economic growth is the major concern for EU policy makers, a potential new member country should minimum have an investment share such that it leaves the weighted average EU investment share at least unchanged. Hence the institutional environment of the new member-which determines at least in part investmentshould have converged to the union's. The reason for this is that-according to the neoclassical model - a decreasing investment share will cause a lower medium run growth rate of average labor productivity, and a lower long-run income level in the enlarged EU compared to the situation without the new member.

However, we did not investigate what causes investment shares to go down nor why possible scale effects which may be observed at the manufacturing level fail to be translated into higher aggregated economic growth. Results from this kind of research may substantially change our 
policy conclusion. The evidence that is put forward should therefore be seen as indicative at best and the analysis should be replicated as additional data become available to check whether the conclusions that we reached can be confirmed. 
APPENDIX I: DATA

\begin{tabular}{|c|c|c|c|c|c|c|}
\hline EU-Stage & בyear & $\begin{array}{l}\text { GDP per } \\
\text { capita }\end{array}$ & $\begin{array}{l}\text { GDP per } \\
\text { worker }\end{array}$ & $\begin{array}{c}\text { Total } \\
\text { population }\end{array}$ & $\begin{array}{c}\text { Total } \\
\text { work force }\end{array}$ & $\begin{array}{c}\text { Investment } \\
\text { in physical } \\
\text { capital }\end{array}$ \\
\hline & & (US\$) & (US\$) & $\begin{array}{l}(\mathrm{x} 1000) \\
\end{array}$ & $\begin{array}{l}(\mathrm{x} 1000) \\
\end{array}$ & 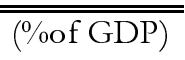 \\
\hline BeNeLux & 1950 & 4518 & 11243 & 19049 & 7655 & 0.2395 \\
\hline BeNeLux & 1951 & 4506 & 11307 & 19224 & 7661 & 0.2252 \\
\hline BeNeLux & 1952 & 4459 & 11282 & 19400 & 7668 & 0.1953 \\
\hline BeNeLux & 1953 & 4684 & 11949 & 19574 & 7673 & 0.2119 \\
\hline BeNeLux & 1954 & 4955 & 12748 & 19750 & 7676 & 0.2381 \\
\hline BeNeLux & 1955 & 5198 & 13489 & 19924 & 7678 & 0.2334 \\
\hline BeNeLux & 1956 & 5399 & 14131 & 20129 & 7690 & 0.2490 \\
\hline BeNeLux & 1957 & 5477 & 14463 & 20334 & 7701 & 0.2533 \\
\hline EEC6 & 1958 & 5071 & 11660 & 168946 & 73468 & 0.2723 \\
\hline EEC6 & 1959 & 5319 & 12278 & 170617 & 73913 & 0.2808 \\
\hline EEC6 & 1960 & 5700 & 13209 & 172241 & 74327 & 0.2970 \\
\hline EEC6 & 1961 & 5979 & 13909 & 173983 & 74790 & 0.3013 \\
\hline EEC6 & 1962 & 6241 & 14574 & 176027 & 75374 & 0.3017 \\
\hline EEC6 & 1963 & 6448 & 15119 & 177978 & 75902 & 0.2974 \\
\hline EEC6 & 1964 & 6773 & 15946 & 179705 & 76330 & 0.3058 \\
\hline EEC6 & 1965 & 7018 & 16587 & 181437 & 76768 & 0.2981 \\
\hline EEC6 & 1966 & 7248 & 17202 & 182938 & 77077 & 0.2954 \\
\hline EEC6 & 1967 & 7450 & 17751 & 183992 & 77215 & 0.2877 \\
\hline EEC6 & 1968 & 7825 & 18726 & 185055 & 77329 & 0.2972 \\
\hline EEC6 & 1969 & 8329 & 20012 & 186538 & 77639 & 0.3080 \\
\hline EEC6 & 1970 & 8762 & 21141 & 188262 & 78031 & 0.3096 \\
\hline EEC6 & 1971 & 8949 & 21818 & 189841 & 77863 & 0.2998 \\
\hline EEC6 & 1972 & 9206 & 22403 & 191143 & 78544 & 0.2959 \\
\hline EEC9 & 1973 & 9631 & 22670 & 256693 & 109045 & 0.2835 \\
\hline EEC9 & 1974 & 9715 & 22818 & 257705 & 109715 & 0.2720 \\
\hline EEC9 & 1975 & 9518 & 22305 & 258254 & 110205 & 0.2355 \\
\hline EEC9 & 1976 & 9979 & 23334 & 258618 & 110598 & 0.2535 \\
\hline EEC9 & 1977 & 10229 & 23861 & 259086 & 111063 & 0.2463 \\
\hline EEC9 & 1978 & 10532 & 24515 & 259584 & 111518 & 0.2415 \\
\hline EEC9 & 1979 & 10931 & 25380 & 260254 & 112085 & 0.2486 \\
\hline EEC9 & 1980 & 11020 & 25528 & 261093 & 112710 & 0.2439 \\
\hline
\end{tabular}




\begin{tabular}{lcccccc}
\hline \hline EU-Stage & year & $\begin{array}{c}\text { GDP per } \\
\text { capita }\end{array}$ & $\begin{array}{c}\text { GDP per } \\
\text { worker }\end{array}$ & $\begin{array}{c}\text { Total } \\
\text { population }\end{array}$ & $\begin{array}{c}\text { Total } \\
\text { work force }\end{array}$ & $\begin{array}{c}\text { Investment } \\
\text { in physical } \\
\text { capital }\end{array}$ \\
\hline \hline & & & & & & \\
EEC10 & 1981 & 10748 & 24838 & 271479 & 117471 & 0.2206 \\
EEC10 & 1982 & 10801 & 24798 & 271984 & 118468 & 0.2190 \\
EEC10 & 1983 & 10959 & 24998 & 272387 & 119410 & 0.2162 \\
EEC10 & 1984 & 11208 & 25401 & 272768 & 120353 & 0.2199 \\
EEC10 & 1985 & 11452 & 25787 & 273292 & 121370 & 0.2180 \\
EEC12 & 1986 & 11100 & 25140 & 322754 & 140353 & 0.2208 \\
EEC12 & 1987 & 11413 & 25765 & 323632 & 141111 & 0.2245 \\
EEC12 & 1988 & 11898 & 26775 & 324678 & 141965 & 0.2353 \\
EEC12 & 1989 & 12284 & 27283 & 325825 & 144316 & 0.2426 \\
EEC12 & 1990 & 12585 & 27821 & 327932 & 145690 & 0.2426 \\
\hline \hline
\end{tabular}

\begin{tabular}{|c|c|c|c|c|c|c|c|}
\hline Country & $\begin{array}{c}\mathrm{EU} \\
\text { member }\end{array}$ & Length & $\overline{l o g}\left(\mathrm{yt}_{\mathrm{t}} / \mathrm{y}_{0}\right)$ & inv. share & $\bar{n}$ & $\mathrm{y}_{0}$ & scale \\
\hline \multicolumn{8}{|c|}{ "BeNeLux } \\
\hline USA & 0 & 0 & 0.114 & 0.222 & 0.012 & 20496 & 161915 \\
\hline Japan & 0 & 0 & 0.493 & 0.192 & 0.020 & 2595 & 87821 \\
\hline Austria & 0 & 0 & 0.461 & 0.199 & -0.003 & 5861 & 6950 \\
\hline Belgium & 1 & 10 & 0.185 & 0.218 & 0.000 & 10934 & 19673 \\
\hline Denmark & 0 & 0 & 0.157 & 0.199 & 0.001 & 10818 & 4387 \\
\hline Finland & 0 & 0 & 0.341 & 0.326 & 0.001 & 6998 & 4165 \\
\hline France & 0 & 0 & 0.343 & 0.208 & 0.002 & 8772 & 42963 \\
\hline Germany & 0 & 0 & 0.529 & 0.285 & 0.011 & 7339 & 51714 \\
\hline Greece & 0 & 0 & 0.372 & 0.144 & 0.009 & 3448 & 7843 \\
\hline Iceland & 0 & 0 & 0.363 & 0.259 & 0.011 & 8685 & 154 \\
\hline Ireland & 0 & 0 & 0.155 & 0.179 & -0.013 & 6313 & 2933 \\
\hline Italy & 0 & 0 & 0.426 & 0.276 & 0.001 & 6286 & 47815 \\
\hline Luxembourg & 1 & 10 & 0.256 & 0.394 & -0.003 & 14159 & 19673 \\
\hline Netherlands & 1 & 10 & 0.269 & 0.234 & 0.002 & 11414 & 19673 \\
\hline Norway & 0 & 0 & 0.277 & 0.321 & 0.001 & 10193 & 3378 \\
\hline Portugal & 0 & 0 & 0.396 & 0.171 & -0.002 & 2935 & 8549 \\
\hline Spain & 0 & 0 & 0.478 & 0.189 & 0.008 & 4988 & 28704 \\
\hline Sweden & 0 & 0 & 0.196 & 0.210 & 0.006 & 13242 & 7185 \\
\hline Switzerland & 0 & 0 & 0.175 & 0.226 & 0.016 & 14971 & 4902 \\
\hline Turkey & 0 & 0 & 0.664 & 0.133 & 0.016 & 1854 & 22989 \\
\hline UK & 0 & 0 & 0.164 & 0.134 & 0.003 & 11665 & 51080 \\
\hline New Zealand & 0 & 0 & 0.067 & 0.270 & 0.020 & 17410 & 2075 \\
\hline Canada & 0 & 0 & 0.176 & 0.245 & 0.021 & 16113 & 15149 \\
\hline
\end{tabular}




\begin{tabular}{|c|c|c|c|c|c|c|c|}
\hline Country & $\begin{array}{c}\mathrm{EU} \\
\text { member }\end{array}$ & Length & $\log \left(y_{t} / y_{0}\right)$ & inv. share & $\mathrm{n}$ & $\mathrm{y}_{0}$ & scale \\
\hline \multicolumn{8}{|c|}{$\overline{\text { EC6 }}$} \\
\hline USA & 0 & 0 & 0.357 & 0.217 & 0.018 & 22876 & 193340 \\
\hline Japan & 0 & 0 & 1.231 & 0.318 & 0.016 & 4179 & 99072 \\
\hline Austria & 0 & 0 & 0.825 & 0.250 & -0.003 & 9129 & 7249 \\
\hline Belgium & 1 & 24 & 0.654 & 0.251 & 0.004 & 13103 & 180580 \\
\hline Denmark & 0 & 0 & 0.546 & 0.276 & 0.012 & 12589 & 4757 \\
\hline Finland & 0 & 0 & 0.709 & 0.366 & 0.007 & 9696 & 4537 \\
\hline France & 1 & 14 & 0.688 & 0.276 & 0.009 & 12258 & 180580 \\
\hline Germany & 1 & 14 & 0.693 & 0.310 & 0.003 & 12211 & 180580 \\
\hline Greece & 0 & 0 & 1.047 & 0.256 & 0.002 & 4941 & 8567 \\
\hline Iceland & 0 & 0 & 0.410 & 0.301 & 0.024 & 12208 & 191 \\
\hline Ireland & 0 & 0 & 0.722 & 0.226 & 0.000 & 7346 & 2891 \\
\hline Italy & 1 & 14 & 0.831 & 0.316 & 0.002 & 9514 & 180580 \\
\hline Luxembourg & 1 & 24 & 0.483 & 0.350 & 0.003 & 17993 & 180580 \\
\hline Netherlands & 1 & 24 & 0.630 & 0.272 & 0.013 & 14754 & 180580 \\
\hline Norway & 0 & 0 & 0.454 & 0.321 & 0.014 & 13374 & 3727 \\
\hline Portugal & 0 & 0 & 0.969 & 0.232 & 0.002 & 4311 & 8966 \\
\hline Spain & 0 & 0 & 0.963 & 0.250 & 0.005 & 7844 & 32090 \\
\hline Sweden & 0 & 0 & 0.406 & 0.252 & 0.012 & 16059 & 7747 \\
\hline Switzerland & 0 & 0 & 0.508 & 0.291 & 0.016 & 17700 & 5820 \\
\hline Turkey & 0 & 0 & 0.503 & 0.185 & 0.016 & 3405 & 31343 \\
\hline UK & 0 & 0 & 0.417 & 0.182 & 0.006 & 13705 & 54206 \\
\hline New Zealand & 0 & 0 & $\begin{array}{r}0.383 \\
\text { EC }\end{array}$ & 0.250 & 0.021 & 18431 & 2617 \\
\hline Canada & 0 & 0 & 0.370 & 0.229 & 0.027 & 19072 & 19616 \\
\hline USA & 0 & 0 & -0.011 & 0.213 & 0.022 & 32488 & 219426 \\
\hline Japan & 0 & 0 & 0.215 & 0.361 & 0.009 & 13568 & 113046 \\
\hline Austria & 0 & 0 & 0.129 & 0.274 & 0.007 & 20303 & 256660 \\
\hline Belgium & 1 & 32 & 0.083 & 0.250 & 0.008 & 24808 & 256660 \\
\hline Denmark & 1 & 7 & -0.015 & 0.268 & 0.011 & 21376 & 256660 \\
\hline Finland & 0 & 0 & 0.131 & 0.352 & 0.008 & 19226 & 4729 \\
\hline France & 1 & 22 & 0.106 & 0.285 & 0.008 & 24002 & 256660 \\
\hline Germany & 1 & 22 & 0.113 & 0.272 & 0.003 & 23956 & 256660 \\
\hline Greece & 0 & 0 & 0.143 & 0.282 & 0.009 & 21251 & 9254 \\
\hline Iceland & 0 & 0 & 0.250 & 0.313 & 0.026 & 17993 & 221 \\
\hline Ireland & 1 & 7 & 0.242 & 0.280 & 0.012 & 14828 & 256660 \\
\hline Italy & 1 & 22 & 0.231 & 0.270 & 0.003 & 21267 & 256660 \\
\hline Luxembourg & 1 & 32 & -0.004 & 0.263 & 0.012 & 28425 & 256660 \\
\hline Netherlands & 1 & 32 & 0.044 & 0.242 & 0.014 & 27257 & 256660 \\
\hline Norway & 0 & 0 & 0.193 & 0.340 & 0.018 & 20897 & 4031 \\
\hline Portugal & 0 & 0 & 0.041 & 0.240 & 0.027 & 10960 & 9284 \\
\hline Spain & 0 & 0 & 0.056 & 0.265 & 0.009 & 19770 & 36131 \\
\hline Sweden & 0 & 0 & 0.030 & 0.232 & 0.010 & 23934 & 8231 \\
\hline Switzerland & 0 & 0 & 0.022 & 0.267 & 0.001 & 29084 & 6370 \\
\hline Turkey & 0 & 0 & 0.194 & 0.240 & 0.017 & 5523 & 41333 \\
\hline UK & 1 & 7 & 0.013 & 0.182 & 0.004 & 20629 & 256660 \\
\hline New Zealand & 0 & 0 & -0.040 & 0.244 & 0.016 & 26645 & 3080 \\
\hline Canada & 0 & 0 & 0.074 & 0.237 & 0.029 & 27426 & 23088 \\
\hline
\end{tabular}

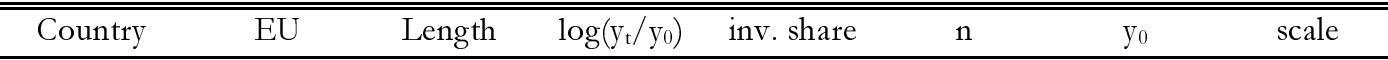




\begin{tabular}{|c|c|c|c|c|c|c|c|}
\hline \multicolumn{8}{|c|}{ member } \\
\hline \multicolumn{8}{|c|}{ EC10 } \\
\hline USA & 0 & 0 & 0.073 & 0.210 & 0.012 & 32023 & 234747 \\
\hline Japan & 0 & 0 & 0.135 & 0.320 & 0.009 & 16745 & 119226 \\
\hline Austria & 0 & 0 & 0.042 & 0.236 & 0.007 & 23037 & 7560 \\
\hline Belgium & 1 & 37 & 0.031 & 0.188 & 0.006 & 26871 & 272382 \\
\hline Denmark & 1 & 13 & 0.164 & 0.202 & 0.006 & 20999 & 272382 \\
\hline Finland & 0 & 0 & 0.100 & 0.316 & 0.009 & 21803 & 4853 \\
\hline France & 1 & 27 & 0.038 & 0.239 & 0.010 & 26635 & 272382 \\
\hline Germany & 1 & 27 & 0.043 & 0.241 & 0.007 & 26733 & 272382 \\
\hline Greece & 1 & 5 & 0.059 & 0.205 & 0.006 & 15496 & 272382 \\
\hline Iceland & 0 & 0 & 0.064 & 0.257 & 0.014 & 22969 & 236 \\
\hline Ireland & 1 & 13 & 0.014 & 0.262 & 0.010 & 18787 & 272382 \\
\hline Italy & 1 & 27 & 0.048 & 0.239 & 0.009 & 26571 & 272382 \\
\hline Luxembourg & 1 & 37 & 0.140 & 0.249 & 0.006 & 28197 & 272382 \\
\hline Netherlands & 1 & 37 & 0.021 & 0.198 & 0.013 & 28437 & 272382 \\
\hline Norway & 0 & 0 & 0.162 & 0.283 & 0.009 & 25281 & 4128 \\
\hline Portugal & 0 & 0 & 0.040 & 0.225 & 0.010 & 11365 & 10008 \\
\hline Spain & 0 & 0 & 0.048 & 0.218 & 0.011 & 20874 & 38165 \\
\hline Sweden & 0 & 0 & 0.090 & 0.194 & 0.004 & 24629 & 8333 \\
\hline Switzerland & 0 & 0 & 0.035 & 0.279 & 0.010 & 29555 & 6415 \\
\hline Turkey & 0 & 0 & 0.139 & 0.224 & 0.027 & 6641 & 47889 \\
\hline UK & 1 & 13 & 0.140 & 0.161 & 0.005 & 20842 & 272382 \\
\hline New Zealand & 0 & 0 & 0.039 & 0.241 & 0.016 & 25464 & 3215 \\
\hline Canada & 0 & 0 & 0.088 & 0.240 & 0.011 & 29481 & 24771 \\
\hline \multicolumn{8}{|c|}{ EC12 } \\
\hline USA & 0 & 0 & 0.087 & 0.210 & 0.009 & 34342 & 246095 \\
\hline Japan & 0 & 0 & 0.214 & 0.349 & 0.007 & 19130 & 122328 \\
\hline Austria & 0 & 0 & 0.134 & 0.250 & 0.008 & 24029 & 7588 \\
\hline Belgium & 1 & 46 & 0.173 & 0.211 & 0.005 & 27697 & 324222 \\
\hline Denmark & 1 & 21 & 0.015 & 0.231 & 0.006 & 24669 & 324222 \\
\hline Finland & 0 & 0 & 0.165 & 0.314 & 0.006 & 24061 & 4941 \\
\hline France & 1 & 36 & 0.119 & 0.258 & 0.009 & 27645 & 324222 \\
\hline Germany & 1 & 36 & 0.073 & 0.242 & 0.022 & 27879 & 324222 \\
\hline Greece & 1 & 13 & 0.097 & 0.180 & 0.004 & 16418 & 324222 \\
\hline Iceland & 0 & 0 & 0.031 & 0.236 & 0.016 & 24421 & 248 \\
\hline Ireland & 1 & 21 & 0.303 & 0.203 & 0.001 & 19033 & 324222 \\
\hline Italy & 1 & 36 & 0.128 & 0.242 & 0.006 & 27849 & 324222 \\
\hline Luxembourg & 1 & 46 & 0.203 & 0.279 & 0.009 & 32332 & 324222 \\
\hline Netherlands & 1 & 46 & 0.094 & 0.218 & 0.013 & 29016 & 324222 \\
\hline Norway & 0 & 0 & -0.016 & 0.275 & 0.011 & 29632 & 4198 \\
\hline Portugal & 1 & 10 & 0.448 & 0.181 & -0.007 & 11817 & 324222 \\
\hline Spain & 1 & 10 & 0.239 & 0.253 & 0.006 & 21875 & 324222 \\
\hline Sweden & 0 & 0 & 0.067 & 0.221 & 0.010 & 26912 & 8426 \\
\hline Switzerland & 0 & 0 & 0.090 & 0.332 & 0.010 & 30565 & 6566 \\
\hline Turkey & 0 & 0 & 0.166 & 0.218 & 0.021 & 7602 & 53194 \\
\hline UK & 1 & 21 & 0.143 & 0.186 & 0.005 & 23931 & 324222 \\
\hline New Zealand & 0 & 0 & -0.050 & 0.246 & 0.013 & 26468 & 3307 \\
\hline Canada & 0 & 0 & 0.090 & 0.268 & 0.011 & 32037 & 25787 \\
\hline
\end{tabular}




\section{REFERENCES}

Aghion, P., And HowitT, P. (1992), “A Model of Growth Through Creative Destruction”, Econometrica, 60: 323-51.

Backus, P., Kehoe, P., Kehoe, T. (1992), "In Search of Scale Effects in Trade and Growth", Journal of Economic Theory, 58: 377-409.

BALDwin, R., AND SEghezZa E. (1996), "Growth and European Integration: Towards an Empirical Assessment”, CEPR Discussion Paper No. 1393.

BARro, R.(1991), "Economic Growth in a Cross Section of Countries", Quarterly Journal of Economics, 2: 407-43.

BARro, R. AND SALA-I-MARTin, X. (1992), "Convergence”, Journal of Political Economy, 100: 22351.

Barro, R. and Sala-I-MarTin, X. (1995), Economic Growth, McGraw-Hill, New York.

Brada, J., AND MÉndeZ, J. (1988), "An Estimate of the Dynamic Effects of Economic Integration", Review of Economics and Statistics, 70: 163-68.

De Melo, J., Montenegro, C., Panagariya, A. (1992), "Regional Integration Old and New: Issues and Evidence". Mimeo. World Bank, Washington DC.

Grossman, G. and Helpman, E. (1989), "Product Development and International Trade", Journal of Political Economy, 97: 1261-83.

Grossman, G. And Helpman, E. (1991), "Quality Ladders in the Theory of Growth”, Review of Economic Studies, 58: 43-61.

Henrekson, M., Torstensson, J., And Torstensson, R. (1997), "Growth Effects of European Integration", European Economic Review, 41: 1537-57.

JONES, C. (1995), "Time Series Tests of Endogenous Growth Models”, Quarterly Journal of Economics, 110:495-525.

Jones, L. AND Manueldi, R. (1980), “A Convex Model of Equilibrium Growth: Theory and Policy Implications", Journal of Political Economy, 98: 1008-38.

Landau, D. (1995), "The Contribution of the European Common Market to the Growth of its Member Countries: an Empirical Test”, Weltwirtschaftliches Archiv, 4: 774-82.

LuCAS, R. (1988), "On the Mechanics of Economic Development", Journal of Monetary Economics, 22: 3-42.

Mankiw, G., Romer, D. And Weil, D. (1992), "A Contribution to the Empirics of Economic Growth”, Quarterly Journal of Economics, 107:407-37.

Nonneman, W. And Vanhoudt, P. (1996), “A Further Augmentation of the Solow Model and the Empirics of Economic Growth for OECD Countries", Quarterly Journal of Economics, 
3:943-53.

Perron, P. (1989), "The Great Crash, the Oil Price Shock and the Unit Root Hypothesis", Econometrica, 57: 1361-1401.

Raymond, J. AND Rich, R. (1997), “Oil and the Macroeconomy: A Markov State-Switching Approach", Journal of Money, Credit, and Banking, 29: 193-213.

Rebello, S. (1991), "Long-Run Policy Analysis and Long-Run Growth", Journal of Political Economy, 99: 500-21.

Rivera-Batiz, L. AND Romer, P. (1991), "Economic Integration and Endogenous Growth", Quarterly Journal of Economics, 106: 531-55.

Romer, P. (1986), "Increasing Returns and Long-Run Growth", Journal of Political Economy, 94:1002-37.

Romer, P. (1990), “Endogenous Technological Change”, Journal of Political Economy, 98:S71-S102.

STOKEY, N. (1988), "Learning by Doing and the Introduction of New Goods", Journal of Political Economy, 96: 701-17.

UzAwa, H. (1964), “Optimal Growth in a Two-Sector Model of Capital Accumulation”, Review of Economic Studies, 31: 1-24.

Young, A. (1995), “Growth Without Scale Effects”, NBER working paper \#5211. 